\title{
Rapid congelation of water by means of hydric (sulphuric) æther and concentrated sulphuric acid
}

\section{R. Hare M.D.}

To cite this article: R. Hare M.D. (1837) Rapid congelation of water by means of hydric (sulphuric) æther and concentrated sulphuric acid, Philosophical Magazine Series 3, 11:67, 325-326, DOI: $10.1080 / 14786443708649286$

To link to this article: http://dx.doi.org/10.1080/14786443708649286

册 Published online: 01 Jun 2009.

Submit your article to this journal

Џ Article views: 2

Q View related articles $₫$ 
of iron when obtained from a filtered infusion of galls and finery cinder, as above described, on being evaporated to the consistency of thick molasses, gum arabic in due proportion having been previously added, forms a pigment which might, it is conceived, supersede Indian ink. When completely dried it glistens like jet with or without the gum.

This tanno-gallate of iron only requires to be dried and ignited at a low red heat, in order to be converted into a pyrophorus. A few years ago Dr. Hare ascertained that, by a similar ignition in close vessels, cyanoferrite of iron, the Prussian blue of commerce, gave a pyrophorus. But as the pure cyano-ferrite of iron, resulting fiom the addition of the ferro-prussiate of potash, more properly the cy ano-ferrite of potassium, to a ferruginous solution did not form a pyrophorus; he was led to believe that the presence of sulphate of alumine in the commercial ['russian blue was the source of the difference, probably by being converted into a sulphide of aluminium, or potassium.

The production of a pyrophorus from the tanno-gallate proves that iron and carbon, when in a state of minute division, are capable, by ignition in close vessels, of acquiring that property of spontaneous combustibility which entitles the body which possesses it to be called a pyrophorus.

In truth these results arc consistent with some facts mentioned by Berzelius, as having been ascertained by Mitcherlich, respecting the spontaneous combustibility of iron, reduced from the state of magnetic oxide to that of the pure metal in an extreme state of division. They are also consistent with the spontaneous combustibility of the residue resulting from the ignition of the oxalate of iron at a red heat.

RAPID CONGELATION OF WATER BY MEANS OF HYDRIC (SU1PHURIC) ETHER AND CONCENTRATED SULPHURIC ACL, \&C. BY R. HARE, M.D.

In freezing water by the vaporization of hydric, commonly called sulphuric, wher, there is much labour in pumping, and the atherial vapour condensing in the pump, disqualifies it for nice experiments until cleansed. Dr. Hare finds that the interposition of sulphuric acid lessens the requisite labour, and protects the pump. By means of a globe or bottle with two tubulures, and a glass funnel with a cock, the acid being in the globe, the water in a retort, and the ether in the funnel, while the two former are exhausted, on allowing the xther to descend upon the water, the congelation of this liquid is instantaneous.

It has been ascertained by the same chemist, that a permanent self-regulating reservoir of chlorine may be made by means of the apparatus heretofore used by him for nitric oxide, substituting for the materials used in that case, manganese in lumps and concentrated muriatic acid.

In one case, Dr. Hare, doubting the purity of the gas, from some 
indications, among others the want of the usual degree of colour, in order to test it exposed leaves of a thin metal called Dutch gold leaf, to a jet of this gas, as he hald previously done repeatedly, without any ill consequence; to his astonishment an explosion took place, which burst the apparatus and produced a detonation as loud as if one of the explosive compounds of chlorine and oxygen had been generated. Yet the only agents employed were peroxide of manganese and chloro-hydric (muriatic) acid. It was the deficiency of intensity in the colour which led him to test it by means of the leat metal. The colour of the protoxide is known to be of a deeper yellow than that of clilorine.

\section{SYNTHESIS OF AMMONIA. BY R. HARE, M.D.}

Understanding that the synthesis of ammonia had been effected by the reaction between nitric oxide and hydrogen promoted by the presence of platina sponge, Dr. Hare, having no knowledge of the process as performed in Furope, succeeded in the following manner in the attainment of that highly interesting result.

Two volumes of nitric oxide and five of hydrogen were introduced into a bell glass with a perforated neck furnished with a cap and cock. At the bottom of a tubulated glass retort, capable of holding about four ounce measures of water, a small heap of platina sponge was made. A leaden pipe communicating with the cock of the bell at one end, and at the other terminating in a copper or glass tube, having a bore about as large as a knitting-needle, was passed through the tubulure so that the orifice of the tube was nearly in contact with the metallic heap. The pipe was made to form an air-tight juncture where it entered the tubulure, and the beak of the retort was recurved so as to be beneath the surface of some water in a wine-glass. 'lhe bell being depressed below the surfice of the water in the pneumatic cistem, the cock was opened as as to allow the gascous mixture to enter the retort and displace the atmospheric air. As soon as this was known to have taken place, by the disappearance of the red fumes resulting from the reaction of the nitric oxide and atmospheric oxygen, the gas being still allowed to pass slowly in bubbles through the water in the wine-glass, an incandescent coal was held near the part of the retort supporting the spongc. The motal being thus heated became ignited, and fumes appeared in the cavity of the retort. An absorption of the water in the wine-glass fullowed, which was however immediately checked by a supply of gas from the bell sufficient to cause the bubbling to recomrience and continue. Under these circumstances the water in the wine-glass acquired the odour of ammonia, and gave with copper the well known blue colour.

In a subsequent experiment a small lump of the sponge was secured in a coil of platina wire and fastened to the tube so as to receive the jet of the mixed gases.

Dr. Hare published the fact, some years since, that asbestus soaked in a solution of chloride of platinum and ignited, would cause the inthammation of hydrogen with oxygen. Ho firds asbestus, si- 